\title{
MORAL VALUE ANALYSIS IN SERAT KITAB KALAM QODRAT FOR WOMEN'S MORAL EDUCATION
}

\author{
Anugrah P. Juniarti, Kundharu Saddhono and Prasetyo Adi W.W \\ Postgraduate Program \\ Sebelas Maret University \\ Email: anugrahjuni94@gmail.com
}

\section{Abstract}

Morality is a personal guide of distinguishing goodness from badness with their mind. Indonesian women, especially Javanese, are perceived to be moral when they possess noble character reflected in gentle, polite, loyal, and religious attitudes. Many Indonesian cultural products portray the ideal female figure in terms of physical to a moral image. One of the cultural products dedicated to illustrate the typical moral for women is Tambang Macapat. Macapat songs containing moral values for women are the song in Serat Kitab Kalam Qodrat (KKQ). This study focuses on examining the content and moral values of Serat KKQ using gender perspective, with a primary emphasis on women's gender. The results can be used as a model for Indonesian women and their character education support. This research is qualitative descriptive with a content analysis method. The primary data are the literary works in KKQ from Mpu Tantular Museum collection, Sidoarjo and the thesis of Sri Sulistianingsih (2016) titled Kalam Qodrat book: text edits and structural analysis. The study results are related to women's morals, respect to parents and a husband (obedient to a husband, loyal, and harmonious), determination, maintaining self-esteem (honor) and the motivation of study.

Moralitas merupakan upaya untuk membimbing manusia menggunakan akalnya untuk membedakan kebaikan dan keburukan. Wanita Indonesia khususnya wanita Jawa disebut bermoral ketika memiliki budi pekerti luhur yang tercermin 
dari sikap lembut, santun, setia dan taat beragama. Banyak produk budaya Indonesia yang menggambarkan sosok perempuan ideal dari segi fisik hingga moralitas. Salah satu produk budaya yang didedikasikan untuk menggambarkan moral ideal bagi perempuan adalah tembang macapat. Salah satu tembang macapat yang memuat nilai moral bagi perempuan adalah tembang macapat yang ada di dalam serat Kitab Kalam Qodrat (KKQ). Fokus studi ini mengkaji isi dan nilai moral dari Serat KKQ menggunakan perspektif gender, dengan fokus utama pada gender perempuan. Hasil kajian dapat digunakan sebagai model bagi perempuan Indonesia serta untuk mendukung pendidikan karakter perempuan. Penelitian ini adalah penelitian deskriptif kualitatif, dengan objek kajian serat KKQ. Menggunakan metode analisis isi. Data utama penelitian ini adalah serat KKQ koleksi museum Mpu Tantular Sidoarjo dan skripsi Sri Sulistianingsih (2016) dengan judul Kitab Kalam Qodrat: suntingan teks dan analisis struktural. Hasil dari penelitian berkaitan dengan moral (akhlak) perempuan, hormat pada orang tua, hormat kepada suami (sikap patuh pada suami, tidak durhaka, setia dan rukun), akhlak berpendirian teguh, menjaga harga diri (kehormatan) serta semangat menuntut ilmu

Keywords: Serat Kitab Kalam Qodrat; Moral Values; Women's Moral; Education.

\section{Introduction}

Morality is a guide to perform the best according to the sense and to give an actual weight for the interests of individuals who will be affected by such action (Rachels, 2004). For example, women are perceived to be moral when they speak softly and politely. It denotes a common perception that women have to set up a better attitude upon daily conduct than men, yet it does not merely mean that men do not need to be moral. Instead, it is due to the different roles and portions of every gender in practice (Rahminawati, 2001; Suhra, 2013).

Endraswara (2013) in his book, Sexology Jawa, argues that Indonesian women, especially Javanese, will be considered moral when they possess a noble character such as tender, loyal, righteous, humble, forgiving, and highly devoted. Thus, moral is the identity of Indonesian women, which needs to preserve and invest in every woman in Indonesia. The image of the ideal female is implicitly and explicitly portrayed in various cultural products not only from physical but also moral aspects (Indradjaja, 2017). 
Tembang Macapat is one of the cultural products with a lot of moral values that women may adapt and use in daily life, such as Serat Dewi Murtasiyah, Serat Candra Rini, Piwulan Estri, Resi Pranawa Kenya, Wulang Putri, and much more (Wulandari, 2016; Saddhono \& Pramestuti, 2018). It is a literary work that functions as entertainment and has positive values worth consuming for society (Basir \& Marifatulloh, 2018). Besides, it also serves to preserve Piwulang Jawa and to evoke the spirit of heroism, education, history, magical, and religiousity (Marsono, 1992). Furthermore, it is a medium that can refine one's character and the taste of beauty, as well as a model of attitude formation of the nation in everyday life (Tedjohadisumarto, 1958; Setiyadi, 2013). Macapat, in the form of a song, becomes one of the developing art among society in all layers (Darmasti, 2011). Therefore, they can easily enjoy and understand Tembang Macapat. Besides, Macapat contains a value and message in which the society can adapt upon daily life (Wangsa et al., 2019). The knowledge and local wisdom of Java, which is usually called Piwulang Macapat, is universal, so its values do not only benefit Javanese (Budiono \& Wiratama, 2017).

There are several types of Macapat songs that mention how women should behave, speak, and live in the community. Macapat portrays women as capable of speaking politely, gracefully, smoothly, and patiently with control in any condition (Wulandari, 2016). Therefore, in addition to media entertainers, Tembang Macapat also contains a reflection of a moral recommended for humankind, including women.

One of Tembang Macapat, which contains adaptable moral values for women, is Serat (the Javanese literary works) Kitab Kalam Qodrat (KKQ). The manuscript collection of Mpu Tantular Museum, Sidoarjo, is Tembang Macapat. It is written in Arabic pegon, and it uses Javanese language and Arabics for some postulates and excerpts from some classical Islamic books. Arabic pegon is employed in the Islamic literary works, including Serat KKQ (Purnama, 2011). Serat KKQ is a Javanese Serat with the history of Arabic King called Imam Sujana, who fought against the infidels (Sulistianingsih, 2016). Besides entertaining cultural products, Serat KKQ also provides moral values and influential Islamic teachings (Sulistianingsih, 2016). Although Serat KKQ tells the history of the King of Saudi Arabia in general, several stanzas are dedicated to discuss the values of morality, which can be adapted by women. The moral values teach how a woman should behave based on religious values in the Quran.

el Harakah Jurnal Budaya Islam Vol. 22 No. 1 Tahun 2020 
The description above bases this study to examine the contents and moral values of Serat KKQ with gender perspective. In this study, the researchers focus on women as the main viewpoint. The study results can be used as a model to inspire Indonesian women and support the character education of women.

\section{Method}

This research is descriptive qualitative, examining the text of Kitab Kalam Qodrat. It employs a content analysis method by collecting some information related to the manuscript content (textology). Content analysis is a kind of research that aims to produce an objective and systematic description of the content and meaning within communication (Krippendorff, 2004; Ratna, 2008). There are six processes of data collection and analysis in the current research. The processes are unitizing, sampling, recording/coding, reducing data to manageable representation, abductively inferring contextual phenomena, narrating the answer to the research question. Unitizing, sampling, recording, and reducing data to compliant representation is one unit of a process called data making (Krippendorff, 2004). Krippendorff (2004) explains that unitizing is the process of systematic classification upon parts of the document with the desired classification form. Sampling is the process of driving excerpts from text or document, which represents the population data to analyze. Recording/coding converts text to be easily understood and interpreted. Abductively inferring contextual phenomena is an analysis process by the researchers based on the context of the document. Narrating the answer to the research question is the process of writing the results of the analysis for an easily understood research report. After all of the data making processes, the researchers analyzed the data using a qualitative approach.

The primary data of the current research are from the manuscript of Kitab Kalam Qodrat, the collection of Mpu Tantular Museum, Sidoarjo and the thesis of Sri Sulistianingsih (2016) titled Kitab Kalam Qodrat: suntingan teks dan analisis struktural. The secondary data to support the research are from books and scientific papers related to the focus of study such as the Quran, the interpretation of Quran, the dictionary of Bausastra. The data were analyzed by using a pragmatic approach. The researcher performed thorough reading, examined the purpose, and found the intended meaning of a text (Sumaryono, 1999). The pragmatic approach was used to understand the text in the manuscript of Kitab Kalam Qodrat, by which interpretation was made. The purpose of the interpretation is to reveal the inferred meanings so that 
it can be correctly understood. According to Martin Heidegger (in Mueller, 1986), every interpretation is an attempt to disclose the hidden meanings.

\section{The Aspects of Moral Education}

Sjarkawi (2014) suggests that moral or morality is the understanding of good and lousy beliefs in specific communities. Meanwhile, according to Suseno (1987), moral always refers to how good or how bad a man is as a human being. Moral values in Indonesia tend to be derived from religious teachings (Sugiyo \& Purwastuti, 2017). In Islam, moral is closely connected to akhlak. Akhlak etymologically refers to ethics, attitude, behavior, and character. Meanwhile, it terminologically means the state of the soul motion that drives into acting by neglecting mind intention (Marzuki, 2015). Moral education generally includes the doctrine and practice of being moral to ourselves, people, environment, and God (Zuriah, 2010).

\section{The Importance of Moral Education for Women}

Women are the source and center of human civilization. In their hands are the future of the nation and humanity at stake. Maqolah of ulama (the saying of Islamic scholars) states Al-Mar'ah 'imad al-bilad. Idza shaluhat shaluha al-bilad, wa idza fasadat fasada al-bilad. It means women are the pillars of a state. If they are good, the country is too, and if it is bad, the country is damaged. Also, a hadith reveals that a good woman (shalihah) is the best jewelry in the world. The hadith shows the importance of having a shalihah woman in the world according to Islam. Besides the fact that a woman (mother) is the first school for children, an Islamic saying which mentions "al-mar'ah 'imad al-bilad" (a woman is the pillar of a country) proves that a woman plays a prominent role in building the moral society.

According to Arwanti (2009), a woman plays a highly significant role, not only a companion to man but also a regulator to the family, the key of the successor of the descent, the supervisor of the child, and the performer of religious activities. Meanwhile, according to Abduh (2011), women, especially those who become mothers, are the central figure of the child's personality formation to possess noble characters.

Thus, being moral is crucial within the woman's life for their significant role in social life. It is the nature that every woman will become a mother. A mother is a central part of a family. Her responsibility is not only to accompany her husband but also to be the first madrasah or school for her children, and 
children are the future generation. Therefore, this nation is expected to have moral women from which the moral and well-mannered generations grow up.

\section{The Moral Values of Women in Serat KKQ}

The analysis of the data in Serat KKQ found some moral values for women. The values are respect to parents, being kind to the husband, strongly determinated to the goodness, diligent during study, and capable of maintaining self-esteem and honor. Below are the explainations of moral education:

\section{Respect to parents}

26. Miwah Dewi Manik Wulan/Ngujungi marang sang aji/Pan sampun tata alenggah/Sang nata andika aris/Kulup sira kang prapti/Dene lawas sira/Kelawan iku sapa/Wong wadon ujung mring mami/lon matur sang perabu Iman Sujana//

27. Punika putra panduka/Manik Wulan putri Ngacih/Kang darbe tirta bilayat/Kawula rebut ngajurit/Sang nata ngandika aris/Yen mengkono nimbok mantu/Pan dene sira ngayuda/Den iring para nerpati/Ratu endi kabeh kang melu ing sira//

XV Sinom, 26-27 (Sulistyaningsih, 2016: 286)

[26. Dewi Manik Wulan approached Sang Aji (the Lord). After sitting down, the king said gently, "My son, now you've come. It has been very long, my son, and who is the girl that gives her honor to me?" Then Prabu Imam Sujana said softly.

27. "She is your daughter, Manik Wulan Putri Ngacih, who has water Bilayat that I seize in the war." The king said slowly, "Then my son-inlaw, why do many kings accompany you at war? Which kings do come with you?"]

The excerpts of Tembang Sinom verse 26-27 in Serat KKQ above show the value of respect to the older people. The moral can be learned from the woman called Dewi Manik Wulan. It tells that when Prabu Imam Sujana (the son of the king) came to see her father with Dewi Manik Wulan, Dewi Manik Wulan honors her father-in-law. Respecting parents-in-law is a form of noble character because they are necessarily the second parents for us. When viewed from religious teachings, respect for parents is suggested to possess by humankind. Quran explains in An-Nisa 36

36. Worship in Allah and do not associate anything with Him. And do good to both your mother-father, relatives, orphans, poor people, close and distant 
neighbors, and peers, ibn sabil and servants. Indeed, Allah does not love those who are arrogant and self-proud (Q.S. An-Nisa' verse 36).

The above excerpts of the song of Sinom explain about the application of a human attitude to parents commanded by Allah in An-Nisa' 36. Therefore, Serat KKQ portrays the attitude of Dewi Manik Wulan, the noble character of a woman to parent-in-law, that can be emulated.

\section{The attitude of wife}

Javanese creates a term kerata basa for a woman, which means wani ditata or willing to be governed by various norms of society and by a husband as the leader of the family. Therefore, her conduct must refer to the norms to have morals and noble character. The social order of Javanese and Islamic teachings suggest that women are the main madrasah (school) for their son so that each should showcase the right attitude as a role model. Besides, they are supposed to be respectful to the husband and the leader of the family, according to Islam. Serat KKQ exposes some lessons about the attitude of a woman or wife in the family, for example, the excerpt of the song Dandhanggula below.

8. Eling-eling putu aja lali/Wong centhola marang ing wong lanang/Apan gedhe durakane/Pan padha klawan guru/Lawan malih kula tuturi/Pertikele wong akrama/Papat kathah hipun/Titi surti lawan guna/Kaping pate anenggih ingkang piranti/Titi pan tegesira //

9. Dipun waged angrawati wadi/Yen wong lanang lagi kedhayohan/Den arum manis tembunge/Klamun bisa sesuguh/Yen tan bisa ngucap den ririh/ Tegese wong surti ika / Weruh semune kakung/Yen kala lakine duka/Aja lunga lan aja ngucap kang nyengit/ Den age ladenana//

10. Yen dhaharan ulate kang manis/Arane guna iku pakarya/ Penggawehane lakine/ Piranti pan tegesipun/Dipun manut karsane laki/ Biso montera kilasa/Manut marang kakung/Lamun abang meluha abang/Lamun putih ya sira meluha putih/Ampun ngantos sulaya//

XXIII Dandhanggula, Stanza 8-10 (Sulistyaningsih, 2016:328)

[8. Bear in mind not to forget the grandchildren, a person who argues against the husband, she is severely sinful, the same as the teacher, and again I suggest, the way people get married, four things to consider; Titi, Surti, Guna, and the forth is Piranti. Titi means

9. Should be able to keep a secret, if her husband welcomes a guest, talk about something good, and give him a treat if you can, if you can't speak softly. Surti means knowing the husband's character; if her husband is angry, if her husband is angry, don't go and don't talk 
fiercely, serve him immediately

10. Serve food in a sweet face. Guna is a job, the responsibility of her husband. Piranti means being obedient to the will of the husband, be attentive as much as possible, if he wants red come in red, if white come in white, do not quarrel]

The above excerpt teaches about the attitude within a marriage, which Serat KKQ group into four: Titi, Surti, Guna, and Piranti. Of the four attitudes in marriage offered in Serat KKQ, three of them are intended for women. It explains that Guna should be practiced by the husband, working hard to provide for his family. While Titi, Surti and Piranti are supposed to be practiced by women within a family.

1) Titi

Titi in Serat KKQ suggests for women to keep the privacy of their family. Besides, if the husband welcomes a guest, the wife should never talk about the wrong side of the family and should give him or her a lovely dish. However, if she cannot afford to serve it, talk about something good.

Surti

Surti in Serat KKQ suggests for a woman to know what makes the husband happy. When her husband is angry, she may not go, may not listen to the husband, and may not offend him. She needs to serve him immediately. If she serves him food, she should also serve him with a smile to please the husband's heart.

Piranti

Piranti includes a woman who suggested attitude to the husband. As a wife, she should follow the will of her husband. If the husband chooses red, she should also choose red. If he chooses white, she also comes with white. It is not encouraged to go against him. As a wife, she is supposed to follow all the decisions of the husband as her sacrifice to keep the family harmonious that no fight between the husband and wife. Common Javanese proverb says, "wong wadon iku swarga nunut neraka katut." It means that a woman is in a position to always come with all the husband's decision.

The three points of the wife's suggested attitude - Titi, Surti and Piranti - further explained separately in the stanzas of Serat KKQ. 


\section{a) Respect to the husband}

Javanese woman holds the principle of respect to the husband and with other people. The principle of respect is based on the opinion that all the relationships among society have been regulated in the hierarchy, that the regulation is worth applying for herself. Therefore, an individual should maintain and act with them (Suseno, 1991). Respect must be addressed to the husband because he is perceived to be the head of the family, fully responsible for the wife's life. Javanese proverb which shows the position of Javanese women within a marriage relationship is suwargo nunut neroko katut. The proverb subjects women who have already been married. It implies that husband achievement in a job, for example, will also bring about happiness to the wife. The moral values of wife's obligations to respect her husband in Serat KKQ is written in Pupuh VII Asmaradana, the fourth stanza:

Upamane wong alaki/Wong wadon gampang binuwang Cowek gopel upamane/ Yen ala gampang binuwang/Mila den bekti sira/Anuta karsane kakung/Laki minangka panutan//

Pupuh VII Asmaradana, Stanza 4 (Sulistyaningsih, 2016:238)

[For example, within marriage, a woman is easily discarded, like a cracked mortar. If she is bad, she will easily be removed. Thus, serve him best, fulfill what he wants. The husband is the role model.]

As portrayed in the fourth stanza of Pupuh VII Asmaradana above, a woman is responsible for respecting her husband. Like a mortar, if it has been gopil or a part of it cracks, it is easily discarded. A man has the right to divorce his wife in some conditions, such as the one described in the book "Fiqh Sunnah Women". It explains "if the wife is bad-tempered, rude, or unexpectable to be an ideal partner to achieve marriage goals (Kamal, 2007). Therefore, a shalihah woman should respect her husband to maintain the harmony of the family.

The respect of a wife towards her husband may be performed in various ways such as the one denoted in the common Javanese wisewords, aja miyak ing wewadine wong kakung which means that a woman is not allowed to spill the secret and disgrace of her husband. It is described in the sixth stanza of Kitab Kalam Qodrat, Pupuh VII Asmaradana:

6. Aja kaya wong sak iki/Alaki pan pepulasan/Alaki pan kaya kebo/Meksih den aku keramat/Ngulari tandhing liyan/Ngrasani alane kakung/Ladak juweh calak lancang //

Pupuh VII Asmaradana, stanza 6-7 (Sulistyaningsih, 2016: 239). 
[6. Never imitate today's people. Getting married for a decoration, Getting married like a beast, claiming for respect, comparing with others, spilling around the badness of her husband, being haughty, talkative, presumptuous upon speaking and behaving].

The first sentence of the sixth stanza of the excerpt reads "never imitate today's people!". The prohibition is written at the beginning of the stanza to strengthen the ban that women should not be violated. In addition, the sentence denotes that the moral or character of women nowadays has been degraded, so they may not be emulated. Today's woman's unrecommended attitudes are portrayed in the next line, which is spilling the badness of her husband and comparing him with others. The bad attitude prohibited in Serat $K K Q$ is relevant to Javanese ethics and Islamic teachings such as the following translation of the Quran:

"... they, your wives are garments for you, and you are garments for them..." (QS. Al-Baqarah: 187)

The above verse describes the duty or role of a wife, which depicts a woman or wife as a cloth for the husband and vice versa. A cloth functions to cover the aurat (body parts which should be covered according to Islam), so it interprets that a woman is responsible for covering the aurat or disgrace of her husband and vice versa.

The other form of a wife's respect to her husband encouraged in the current serat is to follow the orders of the husband. It is described in the second stanza of Pupuh VII Asmaradana which reads

Den bisa sira alaki/Ngladeni marang periya/Aja sembrana lakune/Amanut sembarang karsa/Laki minangka iman/Bongsa iman iku guru/Aja bangkang marang printah//

VII Asmaradana, stanza 2 (Sulistyaningsih, 2016: 238).

[You can get married, serve the husband, do not show a bad attitude, follow every wish he has, a man is the leader, a leader is a teacher, don't argue against his orders].

Following the will of a husband is prominent. This is the application of a wife's respect towards her husband. It is suggested that serving the husband should watch over on attitude, she may not carelessly behave because the man (husband) is the leader. A leader in Serat KQQ is interpreted as a teacher, a man who teaches and guides her, so she must respect and obey all of her orders.

Therefore, a moral woman must respect her husband. It can be performed in various ways. Somehow a wife can show respect to the husband as suggested 
in Serat KKQ. It suggests to follow all of the orders of the husband, not to argue against the husband, closing the badness or the privacy of the husband, and not to compare her husband with other men.

\section{b) The prohibition to rudely argue against a husband}

The discussion related to the morals of a woman may lead to the social perspective that she is a weak, emotional, and maternal creature (Munir, 1999). It is the universal norm among society and religion which demands a woman to apply. The excerpt of Serat KKQ portrays the recommended moral values of a woman, which suggests not to talk rudely to the husband. It reads:

7. ... /Yen den undang laki nipun/Sumahur sarwi anyentak//

8. Lamun den tuturi becik/Ajawal pan jaluk talak/Iku pengagone lunthe Sebaiknya "lonthe")/Pan gugu ujaring tongga/Pan saguh ungkulana/Iya marang laki nipun/Bagus anom tegal sawah//

VII Asmaradana, stanza 7-8 (Sulistyaningsih, 2016:239).

[7. ... if her husband calls upon her, she answers in a high volume.

8. If she is given advice, she is impudent and asks for divorce. She was hussy; she believes in the words of neighbors, more than what she does to her husband-handsome, young, and rich].

The above excerpt teaches the moral value of a woman, not to say rude to the husband. The excerpt explains that a woman who replies rudely (loud and rough) upon her husband's call and who is impudent when given advice is hussy (not a good woman). Therefore, she must behave the other way around, in contrast to the attitudes portrayed above, such as speaking gently to the husband, listening to his good advice, and not quickly asking for a divorce.

\section{c) Obedience to the husband}

Disobedience is reprehensible against both social norms and religion. Serat KKQ bans a wife from being disobedient against the husband.

6. Dipun bukti marang guru laki/Apan laki minangka panutan/Apan guru sejatine/Sampun bangkang marang kakung/Datan becik ingkang pinanggih/Lan sampun dhingin karsa/Dosa kang tinemu/Lan lawan ampun centhula/Raden ayu dhumateng ing guru laki/Pan sampun manah ngiwa//

7. Cecadhange duraka marang laki/Neng ngakherat ula lan kelabang/ Segunung kawi gedhene/Siyungira salumbung/Landhepira kadeya keris/ Nguntal marang wong duraka/Metu saking dubur/Amanjing marang neraka/Luwih panas neraka geni puniki/Ping pitu geni dunya// 
XXIII Dandhanggula, stanza 6-7 (Sulistyaningsih, 2016: 327).

[6. "Prove your husband, that he is a role model, the real teacher, do not be rebellious to the husband, you will not find (obtain) something right, and do not go before your desire (selfish), because sin you will get, and do not be impudent, O Raden Ayu to the husband, and do not follow your heart to the left (bad).

7. If disobedience to the husband, in the afterlife of the snake and the centipede mountain number siungnya of the barn sharp like a dagger swallowing the man of sin and out from the rectum to the entrance to hell, is hell hot from the fire that is seven times the fire in the world.]. The above excerpt from the two stanzas of the song Dandhanggula demonstrates that a woman should not be rebellious to her husband. This attitude is essential because a husband, as portrayed in the sixth stanza, is the teacher or role model for the wife, so she is encouraged to follow his will and prioritize him than her interest. The reason why a woman is discouraged from challenging her husband is that she will be sinful if she goes against him. Besides, the impact of the sin for being rebel to the husband in the hell is that giant snakes and centipedes will eat her up and find the heat of the fire seven times as hot as the heat of the fire in the world. Therefore, it concludes that the recommended moral for a woman is to be obedient to the husband.

d) Loyalty

Another moral of women in Kitab Kalam Qodrat is loyalty to the husband, as stated in the excerpt of Serat KKQ below.

Tan laki pindho ping katri/Tan becik temahanira/Pan amrih ing dunnya bahe/ Nora katemu ing akherat/Mligine wong akrama/Panggiha akherat bayuk/ Alaki padha ngulama//

VII Asmaradana, stanza 5 (Sulistyaningsih, 2016: 239).

[Do not double or triple your husband, it is not good in the end, wishing in the world only, they will not meet in the hereafter, the main reason for getting married, meeting up in the hereafter, getting married to a man like an Islamic leader].

Being loyal is the noble character of a woman. Loyalty is manifested and struggle not to cheat with other men. Besides, it also explains that being disloyal or cheating always does not end well. People who are not loyal to their spouse, mentioned in the above excerpt, will not meet each other again in the hereafter. Loyalty is considered prominent because it may reunite a 
spouse in the hereafter. Therefore, it includes one of the woman's morals within marriage by which she could be fortunate in the world and hereafter.

\section{e) Harmony}

A good woman will always set the family orientation into maintaining the understanding and harmony with either her spouse or other people. Keeping the harmony is her priority. The kind of harmony described in the personality of a female figure in Serat KKQ is in the following excerpt of Pupuh XXXII Pucung, stanza 11-12.

11. Johar Manik angujungi sang perabu/Lajeng lampahira/ Pinarak aneng sitinggil/ Johar Manik wus lajeng ing jero pura//

12. Sampun panggih lan Manik Wulan sang ngayu/Langkung aturira/Dene maru padha putri/Sameya amrih ganjaran aneng ngakherat//

XXXII Pucung, stanza 11-12 (Sulistyaningsih, 2016: 374).

[11. Johar Manik visited (met) Sang Prabu. Then, when he walked, sat on a throne, Johar Manik had come inside the palace.

12. When meeting the beautiful Manik Wulan, she said, "we are the same wife of a king, and we both want a reward in the hereafter."].

The excerpts show that one of the morals of a woman, which is prominent to every individual, is harmony. They suggest the importance of maintaining peace depicted in the harmonious relationship between the Dewi Johar Manik and Dewi Manik Wulan. They are both the same, the wife of Raden Imam Sujan, who get along well during living together. Harmony is constituted from their noble intention of getting married, which is to gain the reward and blessing of God for provision in the hereafter. The balance between both wives is a woman moral to emulate.

The story of the two wives of Sujana also suggests to strengthen an intention. Both female characters' intention upon marriage is to wish for God's blessings to get His reward. It implies a religious teaching, which is straightening the purpose of getting married because marriage primarily aims to worship in Allah.

\section{Strong determination}

Strong determination is a noble character which human should keep. Determination comes from confidence or belief within individual, that the action or decision taken is the truth for him (Rahma et al., 2013). If human beings do not possess determination, they will be more easily trapped in life, leading them to forget about conscience, for example, easily ignoring the spiritual values of truth for the sake of success.

el Harakah Jurnal Budaya Islam Vol. 22 No. 1 Tahun 2020 
24. Raja putri putrane nalendra Ngacih/Karsane kang rama/Den oleh ken ratu kafir/Sang retna den plahur pejah//

25. Retna ayu angsala priyayi mukmin/Punika pan arsa/Kang rujuk elmu sejati/ Amrih slamet ing akherat//

XXI Maskumambang, stanza 24-25 (Sulistyaningsih, 2016: 319).

[24. The king's daughter, the daughter of King Ngacih, her father intended to match her up with a non-Muslim king but the queen will commit suicide.

25. Queen Ayu should get a Muslim, it was the wish of hers, who mastered the actual science to be fortunate in the hereafter].

The excerpts of maskumambang song above, verses 24-25, suggest the example of strong determination. Determination can be learned from the character of the Princess from the Country of Ngacih, when he will be matched up with a non-Muslim king. Then, he firmly refused it because she believed in one thing that she must have a Muslim husband. The above excerpts indicated that the princess from Ngacih refused the recommendation of her father to marry a non-Muslim king. It is not a disgraceful moral because the refusal was not grounded from selfishness but rather religious belief, Islam. Islam forbids a woman to marry a non-Muslim. Thus, she was strongly determined to be married to a Muslim to perform God's command. This is a role model of a proper determination due to religious motifs, not just following the ego and desire.

\section{The motivation to study}

Studying is a noble deed. Quran reads in Al-Mujadalah 11:

God will exalt the degree of those who believe among you and those who were given knowledge (Q.s. Al-Mujadalah: 11)

In compliance with the above Quran verse, KKQ also portrayed the model of a highly motivated woman to study as below.

2. Sang pendhita aturira/Kawula matur sang putri/Pan wonten karsa punapa/ Tedhak dhukuhipun kaki/Dene kadingaren gusti/Sang retna ngandika arum/ Dhingin tinja marang tuwan/Anenggih kang kaping kalih/Rujuaken ing elmu rasa kang mulya//

XXII Sinom, stanza 2 (Sulistyaningsih, 2016: 320).

[2. The Pandita said, "I asked the princess, what do you want, stepping (come) to my small village? It is uncommon for your majesty to come 
here". The queen said gently, "the first is to meet you, the second is to study about noble values].

The above excerpts contain a moral value for women, which was the motivation to study. The value can be learned from the figure of the princess. It strengthens the proves that when the princess came to Pandita for the second time to study about the true science. The character of the princess suggests the importance of education for a woman. The need to study does not only apply to a man but also a woman. We must learn from the spirit of the princess when picking up Pandita to study.

\section{Keeping the honor}

Keeping the honor is an obligation for women in Islam. Allah said in An-nur verse 30:

Say (o Muhammad) that women are subjected to keep their eyes and genitals (Q.S An-Nur:30).

The verse shows that keeping the eyes and genitals or basically maintaining dignity is Sharia (suggestion) of Allah that should be implemented by every woman. One of the moral educations for women is provided in KKQ, which is maintaining self-esteem and dignity. It is described in the following songs:

2. Aja kaya prawan jaman akhir/Derengesan sesaba ing tongga/Lakune den gawe-gawe/Yen ngucap sarwi gumuyu/Cekakaan sarta ceriwis/Matane pendirangan/Yen ana wong bagus/Yen mandeng kumedhep tismak/Bungahbungah kelamun tinari laki/Gumuyu latah-latah//

3. Saben dina angon jaka sigit/Sarwi lagon gendheng tetabuhan/Susune den umbar bae/Nyambut gawe tan purun/Panganane emoh sethithik/Sabendina lonthang-lonthang/Ngiceng omah suwung)/Yen ana jaka anendra/ Iya iku manut penggawene iblis/Ingelmu pan ora doyan//

XXIII Dandhanggula, stanza 2-3 (Sulistyaningsih, 2016: 326).

[2. Don't be such girls nowadays, going around neighbors and gossiping, making up the way they walk, speaking while laughing, roaring without control (hard) and talking a lot, mashers, when they find a handsome man, they stare at him without a single blink, severely delighted with a man's offer, roaring with laughter.

3. Looking for a virgin handsome guy every day, while singing in drum-like a crazy girl, showing off their aurat (her breasts), unwilling to work, reluctant to eat little rice, going around every day, window seeing an empty house to hunt a virgin guy, they follow the act of the devil, they do not love knowledge].

el Harakah Jurnal Budaya Islam Vol. 22 No. 1 Tahun 2020 
The above song of Dandhanggula suggests a woman keep her self-esteem and honor to be noble. The author of Serat KKQ suggests the reader through the excerpts "Don't be such girls nowadays". This phrase portrays the author's view in Serat KKQ against women nowadays who degrade the quality of moral and ethics, so a role model is highly needed. Below are the characters of women who should not be a role model according to Serat KKQ: those who make up the way they walk. It refers to woman who waddles her steps during walking to attract her opposing sex. The second is the woman who cannot speak gently and who roar with laughter because it is impolite. The third is the woman who cannot keep his views down and happy to stare at men who are not her mahram. The forth is a slacker woman. The fifth is the woman who cannot keep her genital (love to commit adultery).

\section{Conclusion}

Tembang Macapat Serat KKQ shows that a song is an expression which becomes a cognition system of Javanese and cultural symbol for education or Piwulang. The examined Piwulang discusses the moral of women, such as respect to parents, respect to the husband which is the act of being obedient to the husband, unprodigal to parents, loyal and harmonious, strongly determinated, maintaining self-esteem and honor as well as highly motivated to study. The different presentation lets the implied knowledge in the song become Javanese wisdom and local culture. Piwulang which is found in Serat KKQ portrays the values which agree with the suggested women's moral in Islam such as being loyal to parents, maintaining self-esteem, obedient and respectful to the husband, studying, consistent, and so forth. Thus, the moral education of a woman in Serat KKQ can be employed as teaching material to build a noble character.

\section{References}

Abduh, B. 2011. Ibu Itu Sungguh Ajaib. Yogyakarta: Transmedia

Al-Quran Terjemahan. 2015. Departemen Agama RI. Bandung: CV Darus Sunnah.

Arwanti, N. M. S. 2009. Swadharma Ibu dalam Keluarga Hindu. Denpasar: WIdya Dharma. 
Budiono, H. \& Wiratama, N.S. 2017. Pendidikan Nilai Dalam Tembang Macapat Dhandanggula. Jurnal Penelitian Pendidikan. 9(1), 1311-1374.

Darmasti. 2011. Kandhasanyata Chants as Aesthetic Expression of Mardusari Female Singer. Harmonia Jurnal Pengetahuan Dan Pemikiran Seni, 11(3), 180-190.

Endraswara, S. 2013. Seksologi Jawa. Jakarta: Wedatama Widya Sastra.

Indradjaja, A. 2017. Penggambaran Ideal Perempuan Jawa pada Masa HinduBuddha : Refleksi pada Arca-arca Perempuan. Purbawidya: Jurnal Penelitian Dan Pengembangan Arkeologi, 6(2), 105. https://doi.org/10.24164/ pw.v6i2.210

Kamal, A. M. 2007. Fiqih Sunnah untuk Perempuan. Jakarta: Al- I'tishom Cahaya Umat.

Munir, L. Z. 1999. Memposisikan Kodrat: Perempuan dan Perubahan dalam Perspektif Islam. Jakarta : Mizan.

Pairin, M. Basir, U., \& Marifatulloh, S. 2018. The Art of Tembang Macapat: Exclusiveness of the Forms, Value Aspects, and Learning Approach. 222(SoSHEC), 226-230. https://doi.org/10.2991/soshec-18.2018.49

Purnama, S. B. 2011. Kesastraan Jawa Pesisiran. Surabaya: Kartika Mulya.

Rahma, A., Wati, G. K., Idris, A. K., \& Moordiningsih, M. I. 2013. Pengeruh Keteguhan Hati Dalam Kehidupan Sosial, Budaya dan Agama : Tinjauan Psikologi Islam dan Psikologi Indegeneus. Islam Dan Peradaban Umat: Bidang Politik Sosial Ekonomi Pendidikan Dan Teknologi, 512-526.

Rahminawati, N. 2001. Isu Kesetaraan Laki-Laki dan Perempuan (Bias Gender). Jurnal Sosial Dan Pengembangan, 17(3), 273-283. https://doi. org/10.29313/mimbar.v17i3.48

Ratna, N. K. 2008. Teori Metode dan Teknik Penelitian Sastra. Yogyakarta: Pustaka Pelajar

Rukiyati S. \& Purwastuti, L. A. 2017. Local Wisdom-Based Character Education Model in Elementary School in Bantul Yogyakarta Indonesia. Sino-US English Teaching, 14(5). https://doi.org/10.17265/1539-8072/2017.05.003 
Saddhono, K., \& Pramestuti, D. 2018. Study of Religious Values Based on Javanese Local Wisdom. El-Harakah, 20(1), 15-32. https://doi. org/10.18860/el.v20i1.4724

Setiyadi, D. B. P. 2013. Discourse analysis of Serat Kalatidha: Javanese cognition system and local wisdom. Asian Journal of Social Sciences $\mathcal{E}$ Humanities, 2(4), 292-300.

Suhra, S. 2013. Kesetaraan Gender dalam Perspektif Al-Qur'an dan Implikasinya terhadap Hukum Islam. Al-Ulum (Gorontalo), 13(2), 373-394.

Sulistianingsih, S. 2016. Kitab Kalam Qodrat: Suntingan Teks dan Kajian Struktural. [Unpublished Thesis]. Surabaya: Universitas Airlangga.

Wangsa, B. S., Suyanto, S., \& Sulistyo, E. T. 2019. A Study on Noble Values of Tembang Macapat Kinanthi in Serat Wulangreh by Pakubuwono IV. 279(Icalc 2018), 170-174. https://doi.org/10.2991/icalc-18.2019.24

Wulandari, A. 2016. Piwulang Estri sebagai Bentuk Reportase tentang Wanita Jawa (Profil Kepemimpinan Raja-Raja Wajo Sulawesi Selatan dalam Lontaraq Akkarungeng Ri Wajo). Manuskripta, 6(2), 1-17.

Zuriah, N. 2010. Pendidikan Moral Ë Budi Pekerti dalam Perspektif Perubahan. Jakarta: Bumi Aksara. 